\title{
Cloning and sequence analysis of an extremely homogeneous tandemly repeated DNA in the grasshopper Eyprepocnemis plorans
}

\author{
M. D. LÓPEZ-LEÓN $† \ddagger, P$. VÁZQUEZ $\$$, G. M. HEWITT $\ddagger$ \& J. P. M. CAMACHO $† *$ \\ †Departamento de Genética, Facultad de Ciencias, Universidad de Granada, E-18071 Granada, Spain and \\ $\ddagger$ School of Biological Sciences, University of East Anglia, Norwich NR4 7TJ, U.K.
}

\begin{abstract}
Digestion of total nuclear DNA of the grasshopper Eyprepocnemis plorans with seven different restriction endonucleases (REs), and subsequent agarose gel electrophoresis, has shown the presence of highly repetitive DNA yielding the typical ladder-like banding pattern. The most clear pattern was produced by DraI, the monomer being some $180 \mathrm{bp}$. This repeat unit was subsequently cloned and sequenced. Bidirectional sequencing of five randomly chosen clones showed exactly the same nucleotides in all 180 positions. The possible explanations for such an extreme homogeneity of this tandem repeat are discussed in the light of current hypotheses on repetitive DNA function and molecular drive mechanisms.
\end{abstract}

Keywords: B chromosomes, DNA sequencing, heterochromatin, repetitive DNA, satellite DNA.

\section{Introduction}

The genomes of most eukaryote organisms contain highly repetitive satellite DNA that is mainly embedded in the constitutive heterochromatin. In most cases, satellite DNA is noncoding and is composed of large arrays of tandemly arranged repetition units (Miklos, 1985). Despite extensive attempts to elucidate the biological role of satellite DNA, no conclusion has yet been reached concerning any possible functional role. For years the most widespread opinion was that it was simply junk DNA lacking any function (Ohno, 1972), or else that it was a selfish class of genomic elements whose only function was their own survival (Doolittle \& Sapienza, 1980; Orgel \& Crick, 1980). These concepts have been challenged in the last few years because functional roles have been demonstrated in some cases (for review, see Haaf et al., 1992; Vogt, 1992; Zuckerkandl, 1992; Irick, 1994).

Most heterochromatic elements in eukaryotic genomes are built from highly repetitive DNA, with

${ }^{*}$ Correspondence. centromeres and telomeres being the most obvious. But eukaryotic genomes also contain additional heterochromatic elements that may be integrated in the standard (A) chromosomes (so called supernumerary chromosome segments) or else constitute independent chromosomes (supernumerary or B chromosomes). These polymorphic heterochromatic genomic elements provide valuable tools for analysing satellite DNA evolution.

The grasshopper Eyprepocnemis plorans has a very complex B chromosome polymorphism, with more than 40 different $\mathrm{B}$ variants described (Camacho et al., 1980; Henriques-Gil et al., 1984; Henriques-Gil \& Arana 1990; López-León et al., 1993). Previous studies have shown that the three more widespread $B$ variants $\left(B_{1}, B_{2}\right.$ and $\left.B_{5}\right)$ lack drive mechanisms (López-León et al., 1992), and that the $\mathrm{B}_{2}$ type is mainly composed of a $180 \mathrm{bp}$ tandem repeat and ribosomal DNA. The $180 \mathrm{bp}$ repeat is present in the paracentromeric regions of most $\mathrm{A}$ chromosomes and in large amounts on the two proximal thirds of the $\mathrm{B}_{2}$ chromosome (López-León et al., 1994). In this report we analyse the sequence of this tandemly repetitive DNA which is shown to be extremely homogeneous; the five clones sequenced showed 
exactly the same DNA sequence, which is most unusual for highly repetitive DNA.

\section{Materials and methods}

\section{Materials}

A sample of adult males of Eyprepocnemis plorans was caught in the province of Granada (Spain). Individuals were frozen in liquid nitrogen and stored at $-80^{\circ} \mathrm{C}$. For chromosome preparation, 10-day-old embryos obtained from several egg pods were fixed as described in Camacho et al. (1991) and stored at $4^{\circ} \mathrm{C}$.

\section{DNA isolation}

Genomic DNA from each grasshopper specimen was obtained by grinding the frozen individual with liquid nitrogen in a mortar. The resulting powder was homogenized and incubated for $30 \mathrm{~min}$ in the extraction buffer $200 \mathrm{~mm}$ EDTA, $10 \mathrm{~mm}$ Tris- $\mathrm{HCl}$, $\mathrm{pH}=8$.

The homogenate was centrifuged at $5000 \mathrm{~g}$ for 10 min, discarding the supernatant and resuspending the pellet in $0.01 \mathrm{M}$ EDTA, $0.3 \mathrm{M}$ Tris- $\mathrm{ClH}, \mathrm{pH}=8$ extraction buffer. Then 10 per cent SDS and proteinase $\mathrm{K}$ (20 $\mathrm{mg} / \mathrm{mL}$ stock) were added to a final concentration of 0.5 per cent and $0.02 \mathrm{mg} / \mathrm{mL}$, respectively, and incubated at $60^{\circ} \mathrm{C}$ overnight.

After one extraction with phenol:chloroform: isoamylalcohol $(25: 24: 1)$, the aqueous phase was treated with DNase-free RNase $(0.05 \mathrm{mg} / \mathrm{mL})$ at $37^{\circ} \mathrm{C}$ for 2 hours. DNA was purified by extracting twice with 1 vol. of phenol:chloroform:isoamylalcohol $(25: 24: 1)$ and once with 1 vol. of chloroform: isoamylalcohol $(24: 1)$, precipitated with 2 vol. of cold ethanol. The DNA pellet was washed in 70 per cent cold ethanol, air-dried and dissolved in the appropiated volume of TE buffer.

\section{RE analysis}

Total genomic DNA was digested with several REs to test for the production of a repetitive DNA band pattern. Digestions were performed overnight with 3-4 $\mu \mathrm{g}$ of DNA and enzyme at 10 units/ $\mu \mathrm{g}$ DNA. The resulting fragments were resolved electrophoretically in 1.5 per cent agarose gel with ethidium bromide. The RE DraI yielded a ladder of repetitive DNA with a prominent band of $180 \mathrm{bp}$. The isolation and purification of this $180 \mathrm{bp}$ band were according to the method described by Koenen (1989).

\section{Cloning and sequencing analysis}

A total of $50 \mathrm{ng}$ of repetitive DNA was ligated to the Smal site of the plasmid pGEM $3 \mathrm{Zf}(+)$ (Promega). The resulting ligation was used to transform competent Escherichia coli JM109 cells. Recombinant clones containing the repetitive DNA fragment of interest were selected by colony colour and digested fragment size.

Recombinant plasmid pGEM $3 \mathrm{Zf}(+)$ templates were sequenced in both directions by the chain terminating method (Sanger et al., 1977) using an automatic ALF sequencer (Pharmacia).

This sequence has been registered in the EMBL data bank with the accession number X75637.

\section{In situ hybridization}

Chromosome preparations were made as described in Camacho et al. (1991) and then dehydrated in 90 per cent ethanol, air-dried and placed in an oven at $37^{\circ} \mathrm{C}$ overnight. Slides were treated with $100 \mu \mathrm{g} / \mu \mathrm{L}$ DNase-free RNase in $2 \times \mathrm{SSC}$ for $1 \mathrm{~h}$ at $37^{\circ} \mathrm{C}$, washed three times in $2 \times$ SSC for $5 \mathrm{~min}$ and dehydrated in an ethanol series.

A probe comprising the recombinant pGEM $3 \mathrm{Zf}(+)$ clone containing the $180 \mathrm{bp}$ repetitive DNA fragment ( $\mathrm{pEpD} 15)$ was labelled by standard nick translation procedures with biotin-7dATP (BRL). 20 $\mu \mathrm{L}$ of hybridization mixture $(10 \mathrm{ng} / \mu \mathrm{L}$ of denatured biotin-7dATP-pEpD15 probe, $2 \times \mathrm{SSC}, 0.6 \mathrm{M} \mathrm{NaCl}$, $10 \mathrm{~mm}$ Tris- $\mathrm{HCl}, 100 \mathrm{~mm}$ EDTA, $5 \times$ Denhardt's solution, 10 per cent dextran sulphate, 50 per cent formamide, $0.3 \mu \mathrm{g} / \mu \mathrm{L}$ denaturated salmon sperm DNA, $\mathrm{pH}=7.5$ ) was loaded onto the slides and covered with a coverslip. Chromosome denaturation was performed on a hot plate at $70^{\circ} \mathrm{C}$ for $10 \mathrm{~min}$ and then the slides were kept in a moist chamber at $37^{\circ} \mathrm{C}$ overnight for hybridization.

Slides were washed with $2 \times \mathrm{SSC}$ for $15 \mathrm{~min}$ at $37^{\circ} \mathrm{C}$ and TMN-TX $\left(2 \mathrm{~mm} \mathrm{MgCl}_{2}, 10 \mathrm{~mm}\right.$ Tris- $\mathrm{HCl}$, $100 \mathrm{~mm} \mathrm{NaCl}, 0.05$ per cent Triton TX-100, $\mathrm{pH}=7.5$ ) for $15 \mathrm{~min}$ at room temperature and blocked with 5 per cent (w/v) BSA (bovine serum albumin) in TMN-TX for $5 \mathrm{~min}$.

For hybridization detection, slides were incubated at $37^{\circ} \mathrm{C}$ for $1 \mathrm{~h}$ with $100 \mu \mathrm{L}$ of a dilution of $1: 250$ of SA-AP (streptavidin-alkalin phosphatase) in TMNTX in a humid chamber. Then they were washed in TMN-TX for $15 \mathrm{~min}$ and in PA (100 mm Tris- $\mathrm{HCl}$, $100 \mathrm{~mm} \mathrm{NaCl}, 50 \mathrm{~mm} \mathrm{MgCl}_{2}, \mathrm{pH}=9.5$ ) for $5 \mathrm{~min}$.

Finally, the staining steps involved adding $150 \mu \mathrm{L}$ of a solution with $4.4 \mu \mathrm{L}$ of NBT and $3.3 \mu \mathrm{L}$ of BCIP (both from BRL) in PA for several min, wash- 
ing in distilled water and counterstaining with Giemsa at 2 per cent in phosphate buffer.

\section{Results}

Total genomic DNA from $E$. plorans was digested by a set of 15 different REs to look for production of repetitive DNA band patterns. Following electrophoresis of the products of different digestions, seven out of 15 enzymes showed repetitive bands: AluI, DraI, EcoRI, EcoRV, MboI, MspI and TaqI. DraI yielded two parallel ladders of repetitive DNA with monomer bands of 200 and $180 \mathrm{bp}$ respectively both in $+B$ and $-B$ individuals (Fig. 1). The present paper concerns the cloning and sequencing of the smaller monomer band. For the moment we do not know whether these two bands correspond to the same repetitive DNA family or not, because although in situ hybridization performed with probes obtained from both bands gave identical results, both being paracentromerically located (Fig. 2), the existence in the same chromosome regions of two different repetitive DNAs with either partial homo-

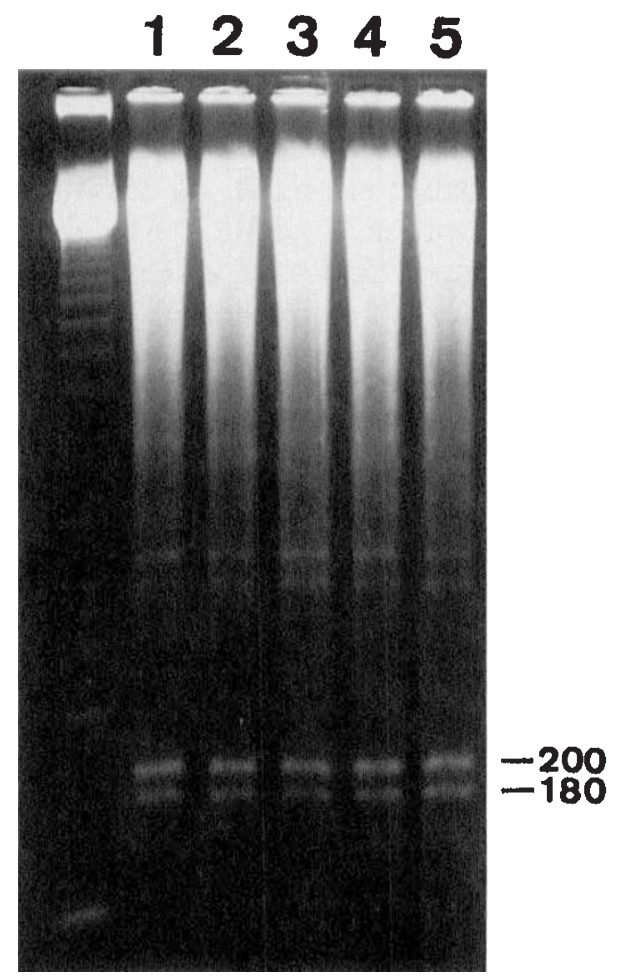

Fig. 1 DraI restriction analysis of total DNA from five different individuals of Eyprepocnemis plorans with $0 \mathrm{~B}$ (lines 1 and 2), 1B (lines 3 and 4) and 2B (line 5). Note the parallel ladder with monmers of about $180 \mathrm{bp}$ and 200 bp in all five individuals. The size marker (on the left) was 123 from BRL. logy or else sharing only a DraI target cannot be ruled out. This point will be clarified in future work.

The DraI satellite 180 bp monomer band was eluted from the agarose gel and cloned into the plasmid pGEM $3 Z f(+)$. Five clones with the insert of interest were randomly selected and their primary structure was determined by sequencing them in both directions. The results showed a nucleotide sequence of $180 \mathrm{bp}$ (Fig. 3) that was exactly the same in the five clones sequenced. Its $\mathrm{A}+\mathrm{T}$ content is $\mathbf{5 8 . 9}$ per cent and it does not possess any direct or inverted subrepeats of significant length (more than seven nucleotides). Likewise, it lacks significant internal complementarity (more than four consecutive bonds) and palindromic regions.

An analysis of the coding capability of the tandem repeat with the CODONPREFERENCE program of the GCG package (Devereux et al., 1984) revealed that this tandemly repeated sequence is very unlikely to encode a protein (Fig. 4). Furthermore, a search of possible homology with other DNA sequences available in the data bank, performed with the FASTA program, revealed no significant similarity with any known DNA sequence.

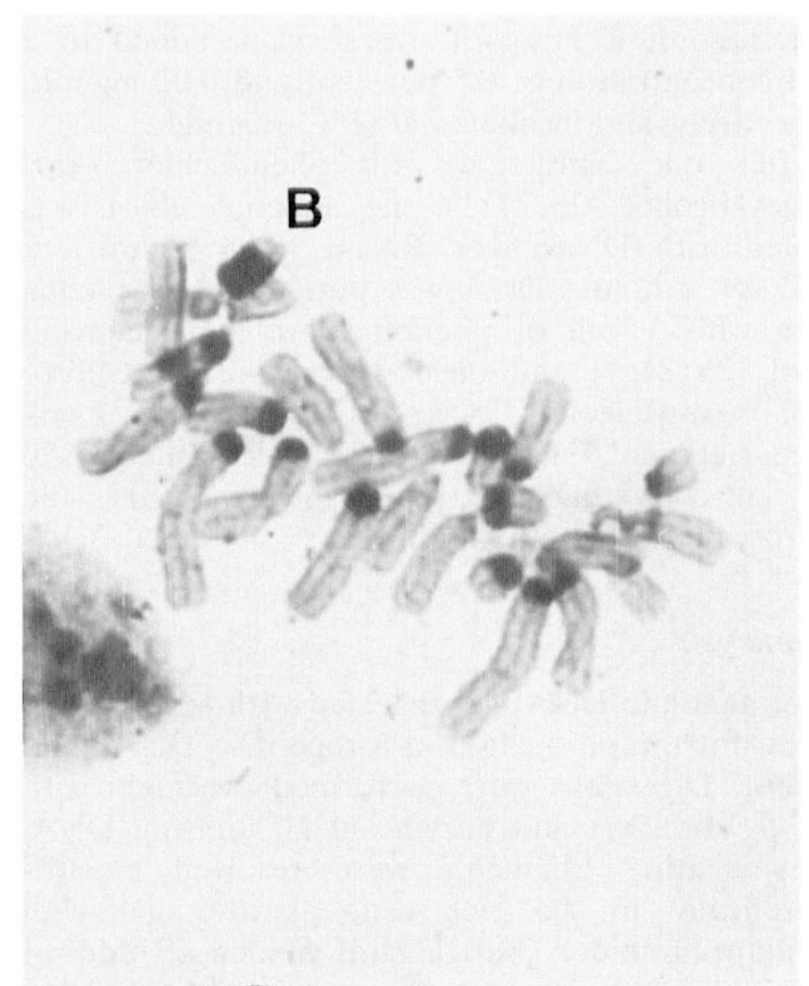

Fig. 2 In situ hybridization with the 180 bp DNA repeat of Eyprepocnemis plorans. Note its presence in paracentromeric regions of most chromosomes, and that the largest cluster is located on the B chromosome.

(C) The Genetical Society of Great Britain, Heredity, 75, 370-375. 
Fig. 3 Sequence observed in all five different clones containing the $180 \mathrm{bp}$ DNA repeat of Eyprepocnemis plorans.

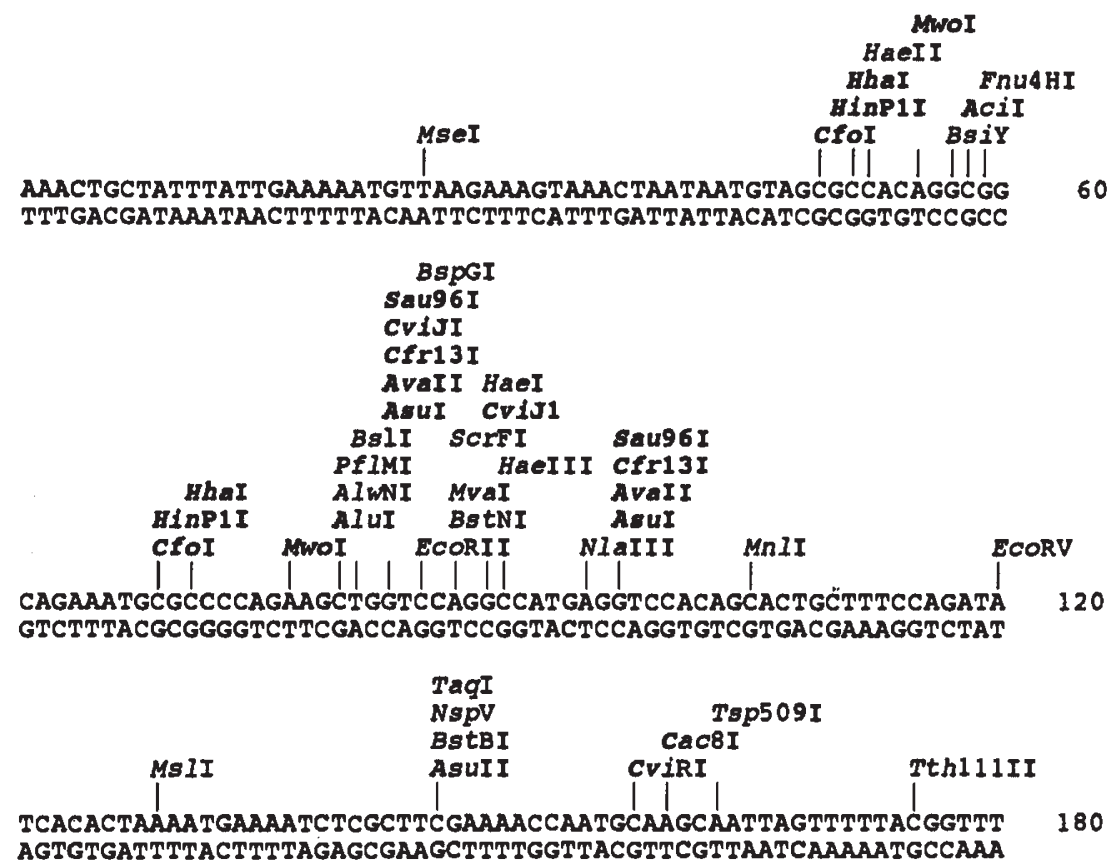

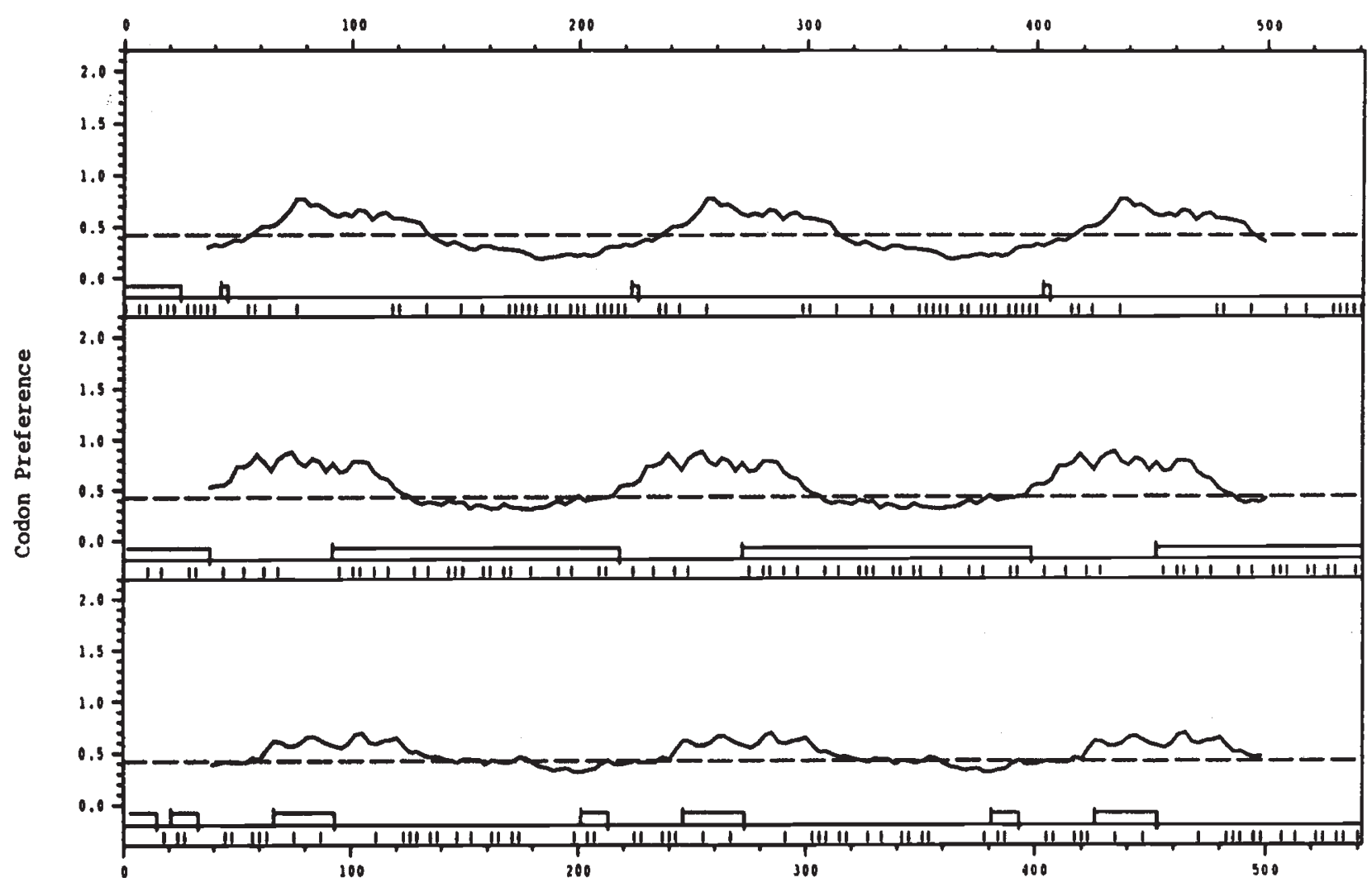

Fig. 4 Coding capability analysis of the 180 bp DNA repeat of Eyprepocnemis plorans with the CODONPREFERENCE program of the GCG package. To facilitate analysis of a complete unit, three tandemly arranged $180 \mathrm{bp}$ repeats were used. Phase no. 2 gave the longer ORF beginning with a ATG codon, with a potential for 42 aminoacids enclosing part of the nucleotide sequence in two consecutive repeats. Codon preference analysis, however, showed that codon usage (curve) for this presumptive polypeptide did not rise significantly above the background (dashed line) when a Drosophila (the closest insect available) codon frequency table was used, thus indicating non-biased codon usage of this sequence. 


\section{Discussion}

The apparent lack of measurable transcriptional activity and the absence of protein coding capability for repetitive DNA, together with rapid changes in sequence, gave birth to the idea that this DNA is simply junk with no functional role (Ohno, 1972). However, this concept has recently been called into question (Zuckerkandl, 1992) and a number of different functions (code domains) are now being envisaged for repetitive DNA (Vogt, 1992). Thus, some satellite DNAs are actually transcribed and the resulting RNA molecules exhibit functional potential by binding specific nuclear proteins (for review, see Pardue \& Hennig, 1990; Doshi et al., 1991; Russel \& Kaiser, 1994). Anyway, it remains true that, for almost all satellite sequences, no function is known, so that considering them as junk DNA is still the prevalent hypothesis.

The extreme homogeneity found among different 180 bp DNA repeats in $E$. plorans is highly remarkable, although the presence of a ladder of fragments, at $180,360,540$ bases etc., indicates that there are variants lacking a DraI site within the arrays and thus the homogeneity of this repetitive DNA family is not absolute. In the abundant recent literature on sequences of tandemly repeated satellite DNA there does not appear to be a comparable case. Even those cases noted for their sequence homogeneity were not as extreme as E. plorans. For example, all six different clones of a 173 bp repeat analysed in Mytilus edulis differed by one or more nucleotides (Ruiz-Lara et al., 1992). Likewise, among 29 different clones of a $180 \mathrm{bp}$ highly repetitive satellite DNA family analysed from Drosophila obscura, $D$. ambigua and $D$. tristis, only two were identical for the whole sequence (Bachmann \& Sperlich, 1993).

Such a high homogeneity of these $180 \mathrm{bp}$ repeats in $E$. plorans could be because of two reasons: i) it has a sequence-dependent functional role, and/or ii) the homogenization mechanisms are extremely effective.

Our results suggest that it is very improbable that the $180 \mathrm{bp}$ repeat codes for any significantly long polypeptide, and, for the moment, we have no evidence for transcriptional activity in this repetitive DNA. The possibility remains, however, that other functions related to protein binding may be associated with this satellite DNA. Athough it is embedded in the paracentromeric heterochromatin of almost all chromosomes, it is separated from the centromere by an amount of rDNA that is variable among chromosomes; consequently, the $E$. plorans $180 \mathrm{bp}$ repeat does not seem to be involved in centromere function. In contrast, it is now known that the human $\alpha$-satellite DNA contains a $17 \mathrm{bp}$ CENP-B box that binds the protein CENP-B (Masumoto et al., 1989) and is directly involved in centromere function (Haaf et al., 1992).

Another possibility is that the $180 \mathrm{bp}$ repeat has something to do with the regulation of the expression of the ribosomal genes to which it is always adjacent. Double fluorescence in situ hybridization (FISH) with this tandem repeat and rDNA showed that i) the repetitive DNA is present in paracentromeric regions of all A chromosomes except 7, 8 and 10 , ii) the rDNA is located also paracentromerically on all A chromosomes, although the most prominent hybridization signals are those of the rRNA gene clusters that are usually active on the $9,10,11$ and $X$ chromosomes, and iii) the $\mathrm{B}_{2}$ chromosome is mainly composed of these two DNA sequences (LópezLeón et al., 1994). In all A chromosomes, except the $\mathrm{X}$ chromosome, the rDNA is located between the centromere and the repetitive DNA. In the $\mathrm{X}$ chromosome, the repetitive DNA is located between the centromere and the rDNA, and this order coincides with that shown by these three elements on the $\mathrm{B}$, which suggested that the $\mathrm{B}$ has possibly arisen from the $X$ chromosome (López-León et al., 1994).

The distribution pattern of rDNA and $180 \mathrm{bp}$ repetitive DNA sequences on $E$. plorans chromosomes suggests that the association between them in most chromosomes may be more than casual. Thus the fact that the repetitive DNA is always located adjacently to rDNA could indicate that both are related in either function and/or origin. Thus, the repeat could play a regulatory role of rRNA genes expression. Furthermore, the tandem repeat could have arisen from the rDNA intergenic spacer, as has been demonstrated in the mung bean, Vigna radiata (Unfried et al., 1991), which is why it is always linked to rRNA genes.

Finally, since the repetitive DNA sequences in $E$. plorans are distal to rDNA in most chromosomes, the extreme homogeneity among repeats could be partly achieved as a consequence of molecular drive (Dover, 1982) for rDNA sequences. Such a process was proposed for the human acrocentric chromosomes carrying the rRNA genes $(13,14,15,21$ and 22) (Worton et al., 1987), on the reasoning that if interchromosomal recombination between rRNA genes is responsible for concerted evolution, one might expect that the sequences distal to the rRNA clusters would be very similar on all of the acrocentric chromosomes.

(C) The Genetical Society of Great Britain, Heredity, 75, 370-375. 


\section{Acknowledgements}

We thank Dr J. L. Oliver for his help with the computer analysis of the DNA sequence and for making Figs 3 and 4, Dr L. Beukeboom, Dr M. Ruiz Rejón, Dr J. L. Oliver and Dr M. Garrido for useful comments, and an anonymous referee for his/her perceptive criticism. This study was supported by grants from the NERC and SERC (U.K.), and the Spanish DGICYT (PB93-1108) and Plan Andaluz de Investigación (Grupo no. 3122). M. D. L. L. was supported by a postdoctoral fellowship from the Universidad de Granada for one year at the University of East Anglia.

\section{References}

BACHMANN, L. AND SPERLICH, D. 1993. Gradual evolution of a specific satellite DNA family in Drosophila ambigua, D. tristis, and D. obscura. Mol. Biol. Evol., 10, 647-659.

CAMACHO, J. P. M., CABRERO, J., VISERAS, E., LOPEZ-LEON, M. D., NAVAS-CASTILlo, J. AND Alche, J. D. 1991. G banding in two species of grasshoppers and its relationship to $\mathrm{C}, \mathrm{N}$, and fluorescence banding techniques. Genome, 34, 638-643.

CAMACHO, J. P. M., CARBALLO, A. R. AND CABRERO, J. 1980. The B-chromosome system of the grasshopper Eyprepocnemis plorans subsp. plorans (Charpentier). Chromosoma, 80, 163-176.

DEVEREUX, J., HAEBERLI, P. AND SMITHIES, O. 1984. A comprehensive set of sequence analysis programs for VAX. Nucl. Acids Res., 12, 387-395.

DoolitTle, w. F. AND SAPIENZA, c. 1980. Selfish genes, the phenotype paradigm and genome evolution. Nature, 284, 601-603.

Doshi, P., KaUshal, s., BeNyajati, C. AND wU, C.--1. 1991. Molecular analysis of the Responder satellite DNA in Drosophila melanogaster: DNA bending, nucleosome structure, and Rsp-binding proteins. Mol. Biol. Evol., 8, 721-741.

DOVER, G. 1982. Molecular drive: a cohesive mode of species evolution. Nature, 299, 111-117.

HAAF, T., WARBURTon, P. E. AND WILlARd, H. F. 1992. Integration of human $\alpha$-satellite DNA into simian chromosomes: centromere protein binding and disruption of normal chromosome segregation. Cell, 70, 681-696.

HENRIQUES-GIL, N. AND ARANA, P. 1990. Origin and substitution of B chromosomes in the grasshopper Eyprepocnemis plorans. Evolution, 44, 747-753.

HENRIQUES-GIL, N., SANTOS, J. L. AND ARANA, P. 1984. Evolution of a complex B-chromosome polymorphism in the grasshopper Eyprepocnemis plorans. Chromosoma, 89, 290-293.
IRICK, H. 1994. A new function for heterochromatin. Chromosoma, 103, 1-3.

KOENEN, M. 1989. Recovery of DNA fragments from agarose gels using liquid nitrogen. Trends Genet., 5, 137.

LOPEZ-LEON, M. D., CABRERO, J., CAMACHO, J. P. M., CANO, M. I. AND SANTOS, J. L. 1992. A widespread B chromosome polymorphism maintained without apparent drive. Evolution, 46, 529-539.

LÓPEZ-LEÓN, M. D., CABRERO, J., PARDO, M. C., VISERAS, E., CAMACHO, J. P. M. AND SANTOS, J. L. 1993. Generating high variability of B chromosomes in Eyprepocnemis plorans (grasshopper). Heredity, 71, 352-362.

LÓPEZ-LEÓN, M. D., NEVES, N., SCHWARZACHER, T., HESLOPHARRISON, T. S., HEWITT, G. M., AND CAMACHO, J. P. M. 1994. Possible origin of a B chromosome deduced from its DNA composition using double FISH technique. Chromosome Research, 2, 87-92.

MASUMOTO, H., MASUKATA, H., MURO, Y., NOZAKI, N. AND OKAZAKI, T. 1989. A human centromere antigen (CENP-B) interacts with a short specific sequence in alphoid DNA, a human centromeric satellite. J. Cell Biol., 109, 1963-1973.

MIKLOS, G. L. G. 1985 . Localized highly repetitive DNA sequences in vertebrate and invertebrate genomes. In: MacIntyre, R. J. (ed.) Molecular Evolutionary Genetics, pp. 241-321. Plenum Press, New York.

OHNO, s. 1972. So much 'junk' data in our genome. In: Smith, H. H. (ed.) Evolution of Genetic Systems, pp. 366-370. Gordon-Breach, New York.

ORGEL, L. E. AND CRICK, F. H. C. 1980. Selfish DNA: the ultimate parasite. Nature, 284, 604-607.

PARDUE, M. L. AND HENNIG, w. 1990. Heterochromatin: junk or collectors item? Chromosoma, 100, 3-7.

RUIZ-LARA, S., PRATS, E., SAINZ, J. AND CORNUDELla, L. 1992. Cloning and characterization of a highly conserved satellite DNA from the mollusc Mytilus edulis. Gene, 117, 237-242.

RUSSEll, S. R. H. AND KAISER, K. 1994. A Drosophila melanogaster chromosome $2 L$ repeat is expressed in the male germ line. Chromosoma, 103, 63-72.

SANGER, F., NICKLEN, S. AND COULSON, A. R. 1977. DNA sequencing with chain-terminating inhibitors. Proc. Natl. Acad. Sci. U.S.A., 74, 5463-5467.

UNFried, K., SCHIEBEL, K. AND HEMLEBEN, v. 1991. Subrepeats of rDNA intergenic spacer present as prominent independent satellite DNA in Vigna radiata but not in Vigna angularis. Gene, 99, 63-68.

vOGT, P. 1992. Code domains in tandem repetitive DNA sequence structures. Chromosoma, 101, 585-589.

WORTON, R. G., SUTHERLAND, J., SYLVESTER, J. E., WILLARD, H. F., BODRUG, S., DUBÉ, I., DUFF, C., KEAN, V., RAY, P. N. AND SCHMICKEL, R. D. 1988. Human ribosomal RNA genes: orientation of the tandem array and conservation of the $5^{\prime}$ end. Science, 239, 64-68.

zUCKERKANDL, E. 1992. Revisiting junk DNA. J. Mol. Evol., 34, 259-271. 